\title{
Impacts of Perceived Role Demands on Work-Life Balance and Moderating Effects of Work Ethics: Evidence from Public Sector Professionals in Sri Lanka
}

\author{
Rajagopalasingam, V. ${ }^{1}$, Fernando, R. L. S. ${ }^{2}$, \& Ramanayake, U. B. ${ }^{3}$ \\ ${ }^{1} \mathrm{PhD}$ Candidate, University of Sri Jayewardenepura, Sri Lanka \\ ${ }^{2}$ Senior Professor, University of Sri Jayewardenepura \\ ${ }^{3}$ Visiting Senior Lecturer, University of Sri Jayewardenepura \\ Correspondence: Rajagopalasingam, V., PhD Candidate, University of Sri Jayewardenepura, Sri Lanka. E-mail: \\ rasagopal2002@yahoo.com
}

Received: June 5, 2020

Accepted: June 28, 2020

Online Published: July 17, 2020

doi:10.5539/ijbm.v15n8p115

URL: https://doi.org/10.5539/ijbm.v15n8p115

\begin{abstract}
Work, family and social life are considered to be the most important spheres for an individual's life. The current study focuses on to determine the level of work-life balance, to analyze the impacts of perceived role demands on work-life balance and to estimate the moderating effects of work ethics between role demands and work-life balance relationship among professionals in Sri Lanka. The sample consists of 386 professionals of Chartered Engineers, Medical Officers and Accountants employed in the public sector organizations in Sri Lanka. Explanatory research design with quantitative research approach of cross sectional survey method was adapted. Primary data was collected using Questionnaire survey with stratified random sampling techniques. Data were analyzed using Structural Equation Modelling approach with Amos 21 and SPSS statistics 23. The Multi-Group Analysis in Amos also has been applied for testing the moderation effect of work ethics. This study found that professionals possess a moderate level of work-life balance and there is significant and negative causal impacts of perceived work and social demands on work-life balance while combined effects of perceived role demands have significantly and negatively impact on work - life balance. Moreover, work-life balance is skewed towards works and less in family and social role demand is an emerging issue for professionals. Further, work ethic has significant and partial moderation effect between role demands and work-life balance relationships. This study is significant and beneficial for managers, organizational leaders and researchers to address the needs of employees to develop strategies and policies to address work - life balance issues and social implications for employees, family members, societies and researchers. The limitation of the study is that all of the measures were self-reported that common method variance may raise concern. Future studies using longitudinal design would be useful in establishing the temporal causal relationship among the private sector professionals in Sri Lanka.
\end{abstract}

Keywords: role demands, work-life balance, work ethics, societies, Sri Lanka

\section{Introduction}

Sri Lanka is a beautiful Island situated in the Indian Ocean with a total population of 21 million. The labour force participation rate of female in Sri Lanka has increased significantly from 25 percent in 1986 and 34.8 percent in 2019 (Dept. of Census, Sri Lanka, 2020). It has been witnessed from literature that major changes have been occurred in work, family and social life domains in terms of economic, demographic, work, social and political contexts in Sri Lanka. Work, family and social domains are vital and inter-connected to people and performing of multiple roles negatively impacts on individuals, families and employing organizations significantly. Mass entry of women into the labour force particularly in service sector leading to increase numbers of dual earners, single parents, dual career couples and elder care related issues. Besides, gender values in terms of male as a breadwinner and female as a home maker ideology is also changing dramatically. Breitenecker and Shah, (2018) stated that work-life balance has indeed become a primary concern to those wishing to have good quality of life. According to Sullivan (2019), research has still indicated that there are significant disparities between men and women pertaining to the work-family balance. Moreover, increase use of information technology and advancement in technology that have made the path to easy access to employer and 
employee is also caused negative interference. Furthermore, work pressure is imposing burdens on professionals and facing difficult in balancing their work and personal life. Balancing a successful career for professionals with personal and family life is indeed challenging due to the fact that the higher the position, the more time and energy that professional must invest in work and life roles. Duxbury et al. (1993) claimed that professionals work longer hours than other groups of workers, which can amplify work-family conflict. Many researchers have claimed that there are interactions between work and life spheres (Clark, 2000; Greenhaus, Collins and Iason, 2003). Under these circumstances, it is evidence that professionals encounter work-life balance issues. Clark (2000) defines work-life balance as satisfaction and good functioning at work and at home with a minimum role of conflict. Devadoss (2013) concluded that work - life imbalance is result to increase the problems related to employee at work place, decrease the productivity and efficiency and cause to increase social hazards such as increasing number of divorces, increase stress levels. Role demands are structural or psychological claims associated with role requirements, expectations and norms to which individuals must respond or adopt by exerting physical or mental effort (Voydanoff, 2004). Boyar et al., (2008) claimed that despite the volume of research explaining the relationship of role demands and work-family balance, role demand conceptualization is problematic as many of the past studies measure role demands objectively. Hence, to fill this gap, perceived role demands were considered in this study. Work ethics is an important work-related construct. Work ethic is basically the belief that work is a good moral and is defined as a set of beliefs and attitudes reflecting the fundamental value of work (Miller et al., 2001). Thus the purpose of this research is to determine the level of work-life balance, to analyze the impacts of perceived role demands on work-life balance and to estimate the moderating effects of work ethics between role demands and work-life balance relationship among professionals employed in the public sector of Sri Lanka.

\section{Literature Review}

\subsection{Work-Life Balance (WLB)}

The origin of the research of work - life balance was found from the seminal work of Rapport and Rapport in1969 and it spells out that both work and family needs time and energy. In defining work-life balance, Work means paid employment while Life means activities outside of paid employment including activities in the household and with friends, family and community. Numerous authors have explained different definitions, conceptualizations, causes, measures and outcomes of work-life balance. Kelliher, Richardson \& Boiarintseva (2018) claimed that academic knowledge around the WLB concept is not as solid and extensive and WLB is a concern mainly for working parents, where caring for dependent children is the relevant load in their life. Further, there has been some debate in the literature about the appropriate terminology to use, with some authors preferring terms such as work-life interface instead (Kelliher, 2016). Wayne et al., (2017) claimed that balance is a different concept from conflict and enrichmen. According to Oludayo et al., (2018), WLB is a concept designed to improve job predictability and career sustainability of employees. Work - life balance is achieving satisfying experiences in all life domains and to do so requires personal resources such as energy, time and commitment to be well distributed across domains (Kirchmeyer, C., 2000). Moreover, based on a critical review of literature, work- life balance conceptualization was classified into seven categories as shown in Table 1.

Table 1. Classification of work- life balance conceptualization

\begin{tabular}{|c|c|c|}
\hline Classification & Source & Conceptualization of work-life balance \\
\hline 1.Satisfaction & $\begin{array}{l}\text { Greenhaus, et al., } \\
\text { (2003). }\end{array}$ & The degree of satisfaction with work and family role. \\
\hline 2.Belief & $\begin{array}{l}\text { Casper, et al., } \\
\text { (2018). }\end{array}$ & $\begin{array}{l}\text { Extent to which employees hold a favorable evaluation regarding their combination of } \\
\text { work and non-work roles, arising from the belief that their emotional experiences, } \\
\text { involvement, and effectiveness in work and non-work roles are commensurate with the } \\
\text { value they attach to the roles. }\end{array}$ \\
\hline 3.Fit & $\begin{array}{l}\text { Crooker, et al., } \\
\text { (2002). }\end{array}$ & A fit between the demands of multiple roles and the availability of personal resources. \\
\hline 4.Equilibrium & Frone, (2003). & Low levels of conflict and high levels of inter-role facilitation. \\
\hline 5.Social Norms & $\begin{array}{l}\text { Grzywacz } \& \\
\text { Carlson,(2007) }\end{array}$ & $\begin{array}{l}\text { Accomplishment of role-related expectations that are negotiated and shared between an } \\
\text { individual and his/her role partners. }\end{array}$ \\
\hline 6.Engagement & $\begin{array}{l}\text { Marks \& } \\
\text { MacDermid, } \\
\text { (1996). }\end{array}$ & $\begin{array}{l}\text { The tendency to become fully engaged in the performance of every role in one's total role } \\
\text { system, to approach every typical role and role partner with an attitude of attentiveness } \\
\text { and care. }\end{array}$ \\
\hline $\begin{array}{l}\text { 7.Miscellaneous } \\
\text { (Others) }\end{array}$ & $\begin{array}{l}\text { Opatha, \& Teong } \\
\text { (2014). }\end{array}$ & $\begin{array}{l}\text { Degree to which one fulfills demands coming and responsibilities arising from his or her } \\
\text { employment and family. }\end{array}$ \\
\hline
\end{tabular}

Source: Researchers. 
Further, Kalliath and Brough (2008) has tested and found six constructs that are related to work-life balance namely (1) multiple roles; (2) equity across multiple roles; (3) satisfaction between multiple roles; (4) fulfillment of role salience between multiple roles (5) a relationship between conflict and facilitation; and (6) perceived control between multiple roles. Meanwhile, work-life balance was addressed by Greenhaus and Allen (2010) as the degree to which the effectiveness and satisfaction experienced by a person in terms of his work and family roles are attuned to his role priorities of life at certain point in time.

According to Shobitha \& Sudarsan (2014), factors affecting work-life balance could be classified as individual factors, organizational factors, societal factors and other factors and outcomes of work life balance can be categorized into two namely work related and non-work related. Pareek and Purohit (2010) has identified six determinants of work-life balance. They are personal needs, social needs, time management, team work, compensation and amount of work given to employees. Work-life imbalance has been consistently linked to negative outcomes for individuals, families and employing organizations. Anitha and Muralidharan, (2014) has studied that demographic factors like age, salary, educational qualification, experience, type of family and spouse working, have impact on work life balance and work related factors like target oriented work, working hours, extended benefits, means of transportation facility also have influence of level of work life balance of marketing professionals. Sonia, Aithal \& Pradeep (2017) have studied about the legal and policy framework for achieving work life balance in organizations and have stated the advantages from the work life balance practices to the organizations, employees and families. Wilkinson Tomlinson and Gardiner's (2017) study found that professional and managers living alone felt their work-life needs were seen as less legitimate than those of colleagues with children because of assumption that their non-work time was entirely leisure-based.

According to Reiter (2007), work- life balance practices were classified as flexible leave arrangements, flexible work arrangements, childcare arrangements, flexible location, employee assistance programs and employee wellness programs. Sirgy and Lee, (2017) found that a poor WLB leads to job and life dissatisfaction, job burnout, depression, irritability, fatigue, and increased blood pressure and cholesterol levels .

Hayman (2005) evaluated 15 items scale of work- life balance adapted from an instrument reported by Fisher et al. (2003) and validated to capture work- life balance measure that is widely used. Theories and models relevant to work-life balance is explained into four perspectives called as conflict perspective, compensation perspective, enrichment perspectives and integration perspectives. Moreover, the working definition of work - life balance is the extent to which an individual combines, prioritizes, attunes and fulfills work, family and social role obligations that represent with experiences of satisfactions, positive gains by interactions and minimum interferences.

\subsection{Role demands and Perceived Role demands}

Katz and Kahn (1978) characterize a role as the building block of social system and the summation of the requirements with which system confront their members as individuals. Demands of a role is the association with responsibilities, requirements, expectations, duties, and commitments with a given role. According to Boyar et al., (2007), demand is a global perception of the level and intensity of responsibility within the work (or family) domain. Additionally, researchers have defined both work and family demand concepts to include variables such as number of hours worked, schedule, role conflict, role ambiguity, role overload, stress from work, marital status, family work hours, number of children at home, and dependents at home (Carlson \& Kacmar,2000; Voydanoff,1988). Moreover, professionals and managers may have more access to greater flexibility relative to other workers enabling them to better cope with the heavy work and family demands (Eaton, 2003; Rau and Hyland, 2002). According to current authors, social demands refer to obligations and commitments of friends and relations, neighbors, community and other relevant parties beyond work, family and self domains. Actually perceived work, family and social role demands are the constructs of interest in this umbrella term of perceived role demands.

\subsection{Work Ethics}

Work ethic is an important work-related construct and basically it is the belief that work is a good moral. Weber (1958) claimed that people would strive for success and wealth because the values associated with the work ethic would become entrenched in society. Work ethic may be defined as a set of beliefs and attitudes reflecting the fundamental value of work (Miller et al. 2001). For the current study, work centrality, self-reliance and hard work dimensions of work ethics were selected as these factors influence more on role demands and work-life balance relationship. Work centrality is defined as individuals' beliefs regarding the degree of importance that work plays in their lives (Paullay et al., 1994). Self-reliance is the individual ability to depend on self to get things done, to meet the needs and make decisions without need of other people. Hard work is the very important 
work ethic and assess one's belief in the virtues of hard work.

Thus, the objectives of this current study was to determine the level of perceived work-life balance and to analyze the impacts of perceived work, family and social role demands on work-life balance with the moderating effect of work ethics among the professionals employed in the public sector of Sri Lanka.

\subsection{Theoretical Model}

On the basis of the literature review, the following theoretical model (Figure 1) has been proposed for the study.

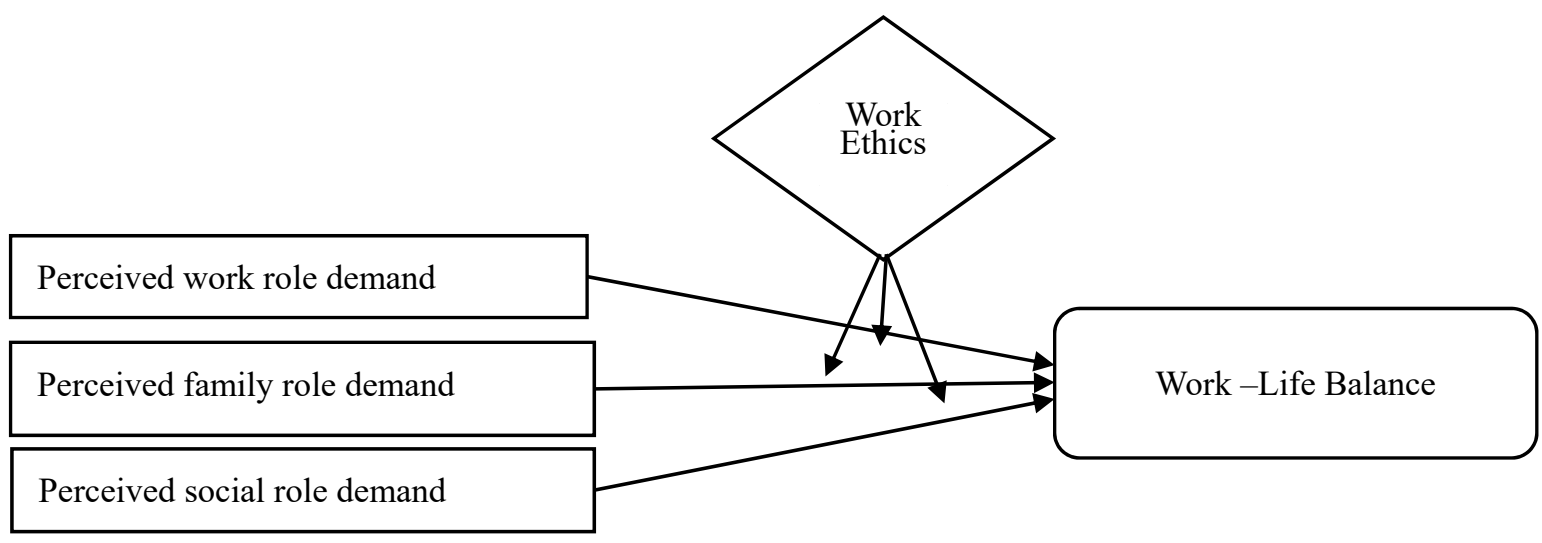

\section{Independent Variable Moderating variable}

\section{Dependent Variable}

Figure 1.Theoretical model of perceived work, family and social role demands and Work- Life Balance

\subsection{Hypotheses}

From the literature review, Sheikh et al. (2018) found that work demands and home demands cause significant effects on work-life balance. In the work of Semlali and Hassi, (2016), it was found that balance is achieved when there is harmony between work and life. Aziz and Chang (2013) claimed that work and family demands effect significantly on work-life balance. Based on the conceptual model, the literature review and the finding of the above researchers, the following hypotheses were postulated.

H1a: Perceived work, family and social role demands have a significant and negative impact on work-life balance.

H1b: Combined effects of perceived work, family and social role demands have a significant and negative effects on work-life balance.

$\mathrm{H} 2$ : Perceived work role demand has the strongest relationship with work-life balance than that of perceived family or social role demands and work-life balance relationships.

H3a: Work Ethics has a moderating effect on the relationship between work-life balance and perceived work, family and social role demands.

H3b: The effects of perceived work role demands on work-life balance will be different between the group with high level of Work-Ethics and the group with low level of Work-Ethics.

\subsection{Theoretical Lenses for the Overall Model}

Theoretical frame work was specified by two theories namely spillover theory and work-family border theory.

\subsubsection{Spillover Theory (Pleck, 1977, \& Lambert, 1990)}

Spill-over theory (Pleck, 1977) has been the most popular theory for examining the work-family interface. According to this theory, workers carry the emotions, attitudes, values, moods, skills and behaviors from their work role into their family life and vice versa (Lambert, 1990). This theory states that spillover can occur in both directions - work to personal life and personal life to work and can have positive or negative effects.

\subsubsection{Work-Family Border Theory (Clark, 2000)}

Border theory persists that work and family are separate but mutually influential domains. It is a theory about work/family balance that explains how individuals manage and negotiate the work and family spheres and the borders between them to attain balance and roles are separated and divided by the boundaries which could be physical, psychological and emotional (Clark, 2000). 


\section{Research Methodology}

\subsection{Research Design}

A cross sectional survey with quantitative data collection approach has been used in this research study. Self-reported structured questionnaires were used to measure the relevant constructs. To meet the research objectives, a structural equation model was developed.

\subsection{Population and Sample}

The population of this research study were twenty four thousand professionals $(24,000)$ of Chartered Engineers, Medical Officers and Accountants employed in the public sector organizations in Sri Lanka. Sekaran (2003) claimed that a population of 10,000 or more, a researcher would probably consider a sample of 384 . According to Yamane's formula, Sample size $n=N / 1+N$ (e) 2 where $N=$ Total population, e = Margin of error $(0.05), n=$ $24000 / 1+24000(0.05) 2=393$.

Hence, sample size for this study was taken as 386 using stratified simple random sampling techniques.

\subsection{Procedure}

Before starting the research study, a pilot study was conducted among 35 professionals of Medical officers, Chartered Engineers and Accountants employed in the public sector organizations in Sri Lanka using simple random sampling techniques. Later, primary data was collected through the use of a written structured questionnaire that was hand delivered and posted by postal mail by using stratified simple random sampling techniques to selected professionals of Chartered Engineers, Medical Officers and Accountants employed in the public sector organizations in Sri Lanka. Each questionnaire was prefaced by a paragraph explaining objectives of the survey. Data collection was taken place during the period of May 2018 to August 2018. A total of 920 questionnaires were distributed and 398 were returned and the response rate was $43.2 \%$. Among them, the questionnaires which contained missing data were deleted, resulting in a total of 386 responses to be used for empirical analyses. Demographic characteristics of participants are given in Table 5.

\subsection{Measures}

The variables used in this study are work-life balance, perceived work, family and social role demands and work ethics and these measures are given below.

\subsubsection{Work-Life Balance Measures}

In this study, researchers developed and validated work -life balance scale has been used. Each dimension consist of three items using a five point Likert Scale ranging from (1) strongly disagree to (5) strongly agree. Work-Life Balance scale altogether contained 13 items and these items are given in Table 2.

Table 2. Work- Life balance measures

\begin{tabular}{|c|c|c|}
\hline WLB - Dimension & Indicator & Item description \\
\hline \multirow{3}{*}{$\begin{array}{l}\text { Satisfaction by Balancing } \\
\text { Work - Personal Life } \\
\text { Interaction. (SBWPLI) }\end{array}$} & WLBS1 & $\begin{array}{l}01 . \text { I feel that I can successfully manage the different aspects of my work and my personal } \\
\text { life. }\end{array}$ \\
\hline & WLBS2 & 02. I am satisfied with the way I divide my time between work and personal life. \\
\hline & WLBS3 & $\begin{array}{l}\text { 03. My prioritizing ability to fulfil the needs of my work with those of my personal life is } \\
\text { satisfactorily. }\end{array}$ \\
\hline \multirow{4}{*}{$\begin{array}{l}\text { Positive Gains by Work- } \\
\text { Personal } \\
\text { Enrichment. (PGWPLE) } \\
\text { (Two directions). }\end{array}$} & WEPL1 & 04. I am feeling a better mood at home because of my work. \\
\hline & WEPL1 & 05. My work helps me to gain knowledge and skills and this helps me in my personal life. \\
\hline & PLEW1 & 06. My personal life energizes me so I can tackle the challenges of my professional career. \\
\hline & PLEW2 & $\begin{array}{l}07 . \text { After spending time with my family members, I go to work with a sense of inner } \\
\text { harmony. }\end{array}$ \\
\hline $\begin{array}{l}\text { Intense Work Negatively } \\
\text { Interfering With Personal }\end{array}$ & WIPL1 & 08. I usually neglect personal needs because of my intense work. \\
\hline Life. (IWIPL) & WIPL2 & 09. My intense work is created a feel of missing personal life. \\
\hline
\end{tabular}




\begin{tabular}{lll}
\hline & WIPL3 & $\begin{array}{l}\text { 10. I am often emotionally drained when I get home from my intense work so that it is } \\
\text { hard to attend my personal life activities. }\end{array}$ \\
$\begin{array}{l}\text { Personal Life Negatively } \\
\text { Interfering With Intense }\end{array}$ & PLIW1 & $\begin{array}{l}\text { 11. My personal life demands are so much so that it takes away from my work energy. } \\
\text { Work. (PLIIW) }\end{array}$ \\
PLIW2 & $\begin{array}{l}\text { 12. I am irritable at my work because of my personal life is demanding a lot. } \\
\text { PLIW3 }\end{array}$ \\
\hline
\end{tabular}

Sources: Authors.

\subsubsection{Perceived Work, Family and Social Role Demands Measures}

Perceived work role demands (PWD) measure was measured using four items developed by Boyar et al. (2007). Perceived family role demands (PFD) measure was measured using three items developed by Boyar et al. (2007) and one item was developed and validated by authors and this item is "I am facing burden on eldercare responsibilities to my family member". Perceived social role demands (PSD) measure was measured using five items developed and validated by current authors and all of these items were anchored using a five point Likert Scale ranging from (1) strongly disagree to (5) strongly agree. These measures are given in Table 3.

Table 3. Perceived Work, Family and Social role demands measures

\begin{tabular}{|c|c|c|}
\hline Construct & Indicator & Item description \\
\hline \multirow{4}{*}{$\begin{array}{lr}\text { Perceived } & \text { Work } \\
\text { role } & \text { demands } \\
(\text { PWD) } & \end{array}$} & WD1 & 1. My job requires all of my attention. \\
\hline & WD2 & 2. I am given a lot of work to do. \\
\hline & WD3 & 3. My work requires a lot from me. \\
\hline & WD4 & 4. I feel like I have a lot of work demand. \\
\hline \multirow{4}{*}{$\begin{array}{l}\text { Perceived Family } \\
\text { role demands (PFD) }\end{array}$} & FD1 & 1. I have to work hard on family-related activities. \\
\hline & FD2 & 2. I have lot responsibility in my family. \\
\hline & FD3 & 3. I feel like I have a lot of family demand. \\
\hline & FD4 & 4. I am facing burden on eldercare responsibilities to my family member \\
\hline \multirow{5}{*}{$\begin{array}{l}\text { Perceived Social } \\
\text { role demands (PSD) }\end{array}$} & SD1 & 1. My neighborhood is safe and convenience to me. \\
\hline & $\mathrm{SD} 2$ & 2. I feel absence of community integrations around my locality. \\
\hline & SD3 & 3. My friends very often make too many demands on me. \\
\hline & SD4 & 4. I cannot make any sense the way my society is going on. \\
\hline & SD5 & 5. My current community based organizational membership is burden to me. \\
\hline
\end{tabular}

Sources: Boyar et al. (2007) and Authors.

\subsubsection{Work Ethics Measures}

Work ethics measures consist of work centrality, self-reliance and hard work and these were measured using three items developed and validated by Miller, Woehr, \& Hudspeth, (2001) as shown in in Table 4. All of these items were anchored using a five point Likert Scale ranging from (1) strongly disagree to (5) strongly agree.

Table 4. Work ethics measures

\begin{tabular}{lll}
\hline Work Ethics & Indicator & Item description \\
\hline Work Centrality & WC1 & 1. I feel content when I have spent the day working. \\
& WC2 & 2. It is very important for me to always be able to work. \\
WC3 & 3. Even, if I inherited a great deal of money, I would continue to work somewhere. \\
Self-reliance & SR1 & 1. One must avoid dependence on other persons whenever possible. \\
& SR2 & 2. Self-reliance is the key to bring successful. \\
Hard Work & 3W & 3. I strive to be self-reliant \\
& HW2 & 2. If you work hard you will succeed. \\
& HW3 & 3. By working hard a person can overcome every obstacle that life presents.
\end{tabular}

Sources: Miller, Woehr, \& Hudspeth, (2001). 


\subsection{Data Analysis}

In this research study, the data collected from research instruments were numerically scored and quantified. Descriptive and Regression analyses were conducted using SPSS 23 to calculate the mean, frequency, standard deviation, correlations and combined effects. Data were also analyzed using Structural Equation Modelling approach with Amos 21(Analysis of Moment structures) to test the fitness of proposed theoretical model and to find the causal effects of perceived role demands on work -life balance. Moreover, Multi-Group Analysis in Amos also has been applied for testing the moderation effect between perceived role demands and work-life balance.

\section{Empirical Results}

\subsection{Demographic Characteristics of Participants}

In terms of demographic analysis of the 386 respondents' demographic characteristics are illustrated in the following Table 5 .

Table 5. The demographic characteristics of the full sample

\begin{tabular}{llllllll}
\hline $\begin{array}{l}\text { Demographic } \\
\text { respondents }\end{array}$ & Details & of & Frequency & $\begin{array}{l}\text { Percentage } \\
(\%)\end{array}$ & Demographic Details of respondents & Frequency & $\begin{array}{l}\text { Percentage } \\
(\%)\end{array}$ \\
\hline Gender & Male & 279 & 72.3 & Marital & Married & 334 & 86.5 \\
& Female & 107 & 27.7 & Status & Single & 41 & 10.6 \\
Professional & Medical & 155 & 40.2 & & Divorced & 2 & 0.5 \\
& Chartered & 126 & 32.6 & & Separated & 2 & 0.5 \\
& Accountants & 105 & 27.2 & & Widow/Widower & 7 & 1.9 \\
Age group & 22-35 & 85 & 22.0 & Tenure & Less than 5 years & 82 & 21.2 \\
& 36-50 & 161 & 41.7 & & 5 years $-<10$ years & 88 & 22.8 \\
Family & 51-61 & 140 & 36.3 & & 10 years $-<15$ years & 74 & 19.2 \\
Structure & Extended & 187 & 48.4 & & 15 years $-<20$ years & 98 & 25.4 \\
Education & Nucleolus & 199 & 51.6 & & 20 years and above & 44 & 11.4 \\
& G.C.E A/L & 3 & 00.8 & Ethnic & Sinhalese & 199 & 51.6 \\
& Bachelor & 210 & 54.4 & Group & Sri Lankan Tamils & 126 & 32.6 \\
& PG Diploma & 80 & 20.7 & & Sri Lankan Muslims & 55 & 14.2 \\
& PG Degree & 93 & 24.1 & & Indian Tamils & 6 & 1.6 \\
\hline
\end{tabular}

\subsection{Reliability and Validity Analysis of Measurement Constructs}

The measurement constructs consist of five latent variables called as work role demands, family role demands, social role demands, work-life balance and work ethics and containing 35 observed variables.

\subsubsection{Reliability Analysis}

The internal consistency reliability of the measured variables were analyzed using IBM SPSS statistics 23 for Cronbach's Alpha values $(\alpha)$. The reliability values for all measured variables ranged from 0.792 to 0.912 and all values were within threshold values. The threshold of Cronbach's Alpha value should be more than .7 (Nunnally, 1978). The Composite Reliability (CR) indicates the reliability and internal consistency of a latent constructs ranged from 0.819 to 0.912 . The cut off value of composite reliability was 0.6 (Fornell \& Larker, 1981). These reliability information are shown in Table 2 . Hence, it was concluded that measurement properties for each variable was reliable.

\subsubsection{Convergent Validity}

Convergent validity was established both by using standardized loadings and Average Variance Extracted (AVE). If an item loads significantly $>0.5$ (Field, 2009, p. 648) on the factor, it is ensure the convergent validity is prevalent. The Confirmatory Factor Analysis (CFA) showed that each item loading is greater than 0.5. Calculated Average Variance Extracted values as per Table 6 are ranged from 0.531 to 0.775 . AVE $>0.5$ (Fornell \& Larker, 1981 ) is required for every construct for ensuring the convergent validity. Accordingly all variables are satisfied to ensure convergent validity as illustrated in Table 6.

$$
\mathrm{AVE}=\sum \mathrm{K} 2 / \mathrm{n}-\mathrm{K}=\text { factor loading of every item, } \mathrm{n}=\text { number of items in a model }
$$

$$
\mathrm{CR}=\left(\sum \mathrm{K}\right) 2 /\left[\left(\sum \mathrm{K}\right) 2+\left(\sum 1-\mathrm{K} 2\right)\right]
$$


Table 6. Factor Loading, Cronbach's alpha reliability coefficient, average variance extracted and composite reliability of constructs

\begin{tabular}{|c|c|c|c|c|c|c|}
\hline Variable & Items & $\begin{array}{l}\text { Factor } \\
\text { Loading }\end{array}$ & $\begin{array}{l}\text { Cronbach's Alpha if } \\
\text { Item deleted }\end{array}$ & $\begin{array}{l}\text { Cronbach's } \\
\text { Alpha }(\alpha)\end{array}$ & AVE & $\mathrm{CR}$ \\
\hline $\begin{array}{l}\text { Work - Life Balance } \\
\text { (WLB) }\end{array}$ & $\begin{array}{l}\text { SBWPLIL } \\
\text { PGWPLE } \\
\text { IWIPL } \\
\text { PLIIW }\end{array}$ & $\begin{array}{l}0.86 \\
0.90 \\
0.82 \\
0.73\end{array}$ & $\begin{array}{l}0.767 \\
0.756 \\
0.758 \\
0.830\end{array}$ & .826 & 0.689 & 0.898 \\
\hline $\begin{array}{l}\text { Perceived work role } \\
\text { demands (PWD) }\end{array}$ & $\begin{array}{l}\text { WD1 } \\
\text { WD2 } \\
\text { WD3 } \\
\text { WD4 }\end{array}$ & $\begin{array}{l}0.76 \\
0.91 \\
0.91 \\
0.67\end{array}$ & $\begin{array}{l}0.859 \\
0.828 \\
0.836 \\
0.884\end{array}$ & 0.888 & 0.671 & 0.889 \\
\hline $\begin{array}{l}\text { Perceived family role } \\
\text { demands (PFD) }\end{array}$ & $\begin{array}{l}\text { FD1 } \\
\text { FD2 } \\
\text { FD3 } \\
\text { FD4 }\end{array}$ & $\begin{array}{l}0.89 \\
0.86 \\
0.76 \\
0.73\end{array}$ & $\begin{array}{l}0.833 \\
0.851 \\
0.859 \\
0.871\end{array}$ & 0.886 & 0.661 & 0.884 \\
\hline $\begin{array}{l}\text { Perceived social role } \\
\text { demands (PSD) }\end{array}$ & $\begin{array}{l}\text { SD1 } \\
\text { SD2 } \\
\text { SD3 } \\
\text { SD4 } \\
\text { SD5 }\end{array}$ & $\begin{array}{l}0.71 \\
0.72 \\
0.72 \\
0.79 \\
0.70\end{array}$ & $\begin{array}{l}0.818 \\
0.818 \\
0.818 \\
0.802 \\
0.825\end{array}$ & 0.848 & 0.531 & 0.850 \\
\hline $\begin{array}{l}\text { Work } \\
\text { Centrality (WC) }\end{array}$ & $\begin{array}{l}\text { WC1 } \\
\text { WC2 } \\
\text { WC3 }\end{array}$ & $\begin{array}{l}0.86 \\
0.89 \\
0.89\end{array}$ & $\begin{array}{l}0.886 \\
0.867 \\
0.866\end{array}$ & 0.912 & 0.775 & 0.912 \\
\hline Self-Reliance (SR) & $\begin{array}{l}\text { SR1 } \\
\text { SR2 } \\
\text { SR3 }\end{array}$ & $\begin{array}{l}0.90 \\
0.88 \\
0.51\end{array}$ & $\begin{array}{l}0.618 \\
0.630 \\
0.883\end{array}$ & 0.792 & 0.615 & 0.819 \\
\hline Hard Work (HW) & $\begin{array}{l}\text { HW1 } \\
\text { HW2 } \\
\text { HW3 }\end{array}$ & $\begin{array}{l}0.83 \\
0.87 \\
0.79 \\
\end{array}$ & $\begin{array}{l}0.812 \\
0.787 \\
0.840 \\
\end{array}$ & 0.868 & 0.690 & 0.870 \\
\hline
\end{tabular}

\subsubsection{Discriminant Validity}

Discriminant validity test was assessed using correlation matrix with square root of the average variance extracted value as shown in Table 7. This shows that square root of average variance extracted for each construct (Diagonals) interactions were greater than the inter construct correlations. Hence discriminant validity has been established.

Table 7. Discriminant validity

\begin{tabular}{lllll}
\hline Variables & 1 & 2 & 3 & 4 \\
\hline 1.WLB & $\mathbf{. 8 3 0}$ & & & \\
2.PWD & $-.507^{* *}$ & $\mathbf{. 8 1 9}$ & & \\
3.PFD & $-.434^{* *}$ & .588 & $\mathbf{8 1 3}$ & \\
4.PSD & $-.246^{* *}$ & .210 & .392 & $\mathbf{. 7 2 9}$ \\
\hline
\end{tabular}

Diagonals represents square root of average variance extracted while off diagonals represents correlations

WLB - Work - Life Balance, PWD- Perceived work role demands, PFD- Perceived family role demands, PSD- Perceived social role demands

\subsection{Results of Descriptive Statistical Analysis}

Descriptive analysis was performed to find out the mean, standard deviation and correlations among all study variables. The researchers define three categories of level of work- life balance based on the mean value. They are (a) Low work- life balance Score < 2.61 (Mean - 0.5 S.D.) (b) Moderate work- life balance Score between 2.61 (Mean - 0.5 S. D.) and 3.41 (Mean + 0.5 S.D.) (c) High work- life balance Score > 3.41 (Mean + 0.5 S.D.) based on five point Likert scale. Considering the overall level of work- life balance, the findings revealed that mean value was in the moderate category $(\mathrm{M}=3.01, \mathrm{SD}=0.80)$. It was identified that $32.12 \%$ of the respondents 
perceive low level of work- life balance whereas $30.83 \%$ of the respondents perceive moderate level of worklife balance and $37.05 \%$ of the respondents perceive high level of work- life balance as shown in Table 8 .

Table 8. Level of professionals' work - life balance

\begin{tabular}{clllll}
\hline Construct & Level of work-life balance & Frequency & Percentage (\%) & Mean & $\begin{array}{l}\text { Standard } \\
\text { Deviation }\end{array}$ \\
\hline Work - Life & Low $(<2.61)$ & 124 & 32.12 & \\
Balance & Moderate $(2.61>\&<3.41)$ & 119 & 30.83 & 3.01 & 0.80 \\
& High $(>3.41)$ & 143 & 37.05 & & \\
\hline
\end{tabular}

\subsection{Results of the Basic Structural Model}

The Structural Equation Modelling (SEM) with maximum likelihood method was used for identifying the relationship between perceived role demands and work- life balance. Before analyzing the basic model, skewness and kurtosis test for each variables were conducted for the validation of normal distribution and the results are compatible with standard (skewness was less than 2 and kurtosis was less than 4). Figure 2 shows the basic structural model of the study variables and Table 9 contains the results of the goodness of fit indices of the basic model.

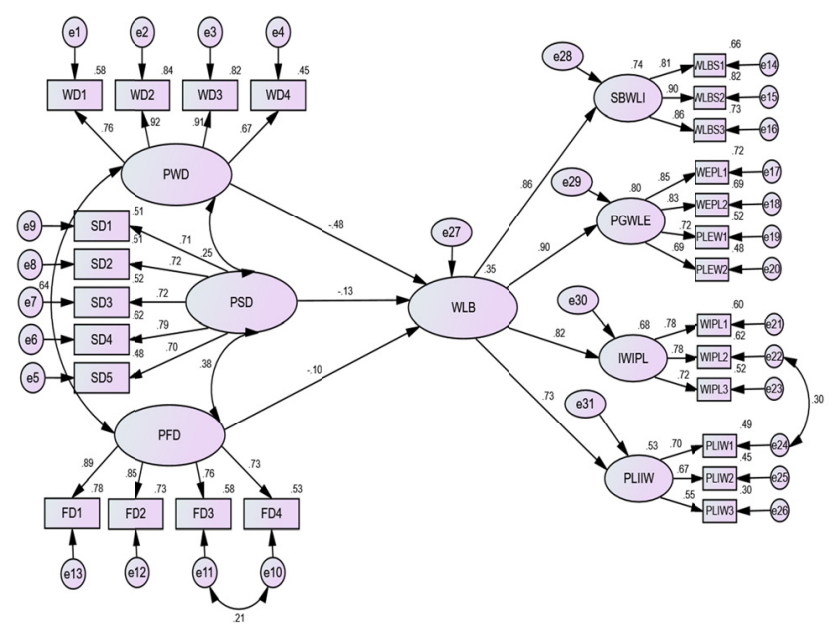

Figure 2. Basic Structural model with significant pathways of focal constructs

\subsection{Results of the Modified Structural Model and Modified Model Fit Indices}

The basic structural model was modified by free estimating between e16 and e29 from the output of modification index $(19.68 \geq 15)$ identified and balance some parts were not revised based on the theoretical basis. All indices of the modified model were better than basic structural model. Figure 3 depicts the modified structural model and model fit indices of modified structural model and Threshold values are illustrated in Table 9. 


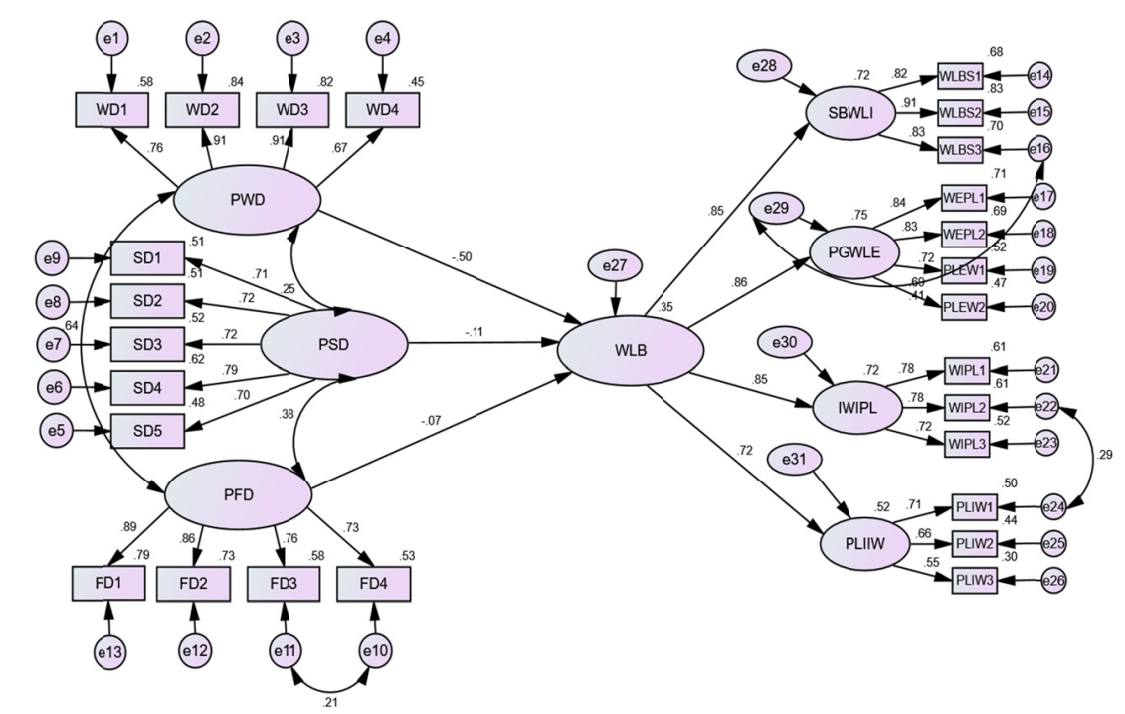

Figure 3. Modified Structural model with significant pathways of focal constructs

Table 9. Goodness of fit of structural equation model

\begin{tabular}{|c|c|c|c|c|c|c|c|c|c|c|c|}
\hline \multirow{2}{*}{$\begin{array}{l}\text { Fit Statistics } \\
\text { Indicators }\end{array}$} & \multicolumn{5}{|c|}{ Absolute Fit Index } & \multicolumn{3}{|c|}{ Incremental Fit Index } & \multicolumn{3}{|c|}{ Parsimonious Fit Index } \\
\hline & $x^{2}$ & $\mathrm{df}$ & RMSEA & RMR & GFI & TLI & NFI & CFI & AGFI & $\chi^{2 / \mathrm{df}}$ & PCFI \\
\hline Basic Model & 716.37 & 287 & .062 & .084 & .874 & .917 & .884 & .926 & .846 & 2.496 & .818 \\
\hline Modified & 693.56 & 286 & 0.061 & .086 & .879 & .921 & .887 & .930 & .851 & 2.425 & .818 \\
\hline $\begin{array}{l}\text { model } \\
\text { Threshold } \\
\text { value }\end{array}$ & Min & Max & $0.05-0.08$ & $\begin{array}{l}0.05-0 . \\
08\end{array}$ & $\geq 0.9$ & $\geq 0.9$ & $\geq 0.9$ & $\geq 0.9$ & $\geq 0.9$ & $1-3$ & Compare \\
\hline Acceptance & Yes & Yes & Yes & Yes & Yes & Yes & Yes & Yes & Yes. & Yes & Yes \\
\hline
\end{tabular}

$\mathrm{P}=.000$, (Less than 0.01) \& Threshold value from Zainudeen (2014).

\subsection{Results of regression Analysis and Hypothesis Testing}

Critical Ratio is the commonly recommended basis for testing statistical significance of SEM components with C.R values beyond \pm 2.58 establishing significance at $\mathrm{P}<0.01$ level. Beta values presented in Table 10 are path coefficients or standardized regression coefficients that indicate the direct effect of independent variable on dependent variable.

Table 10. Standardized $(\beta)$ and Unstandardized (B) Regression Estimates

\begin{tabular}{lllllll}
\hline Construct \& Path & B & $\beta$ & SE & C.R & p & Results of significance \\
\hline WLB $\longleftarrow$ PWD & -.437 & -.503 & .066 & -6.666 & .000 & Significance \\
WLB $\longleftarrow$ PFD & -.064 & -.068 & .069 & -0.928 & -.353 & Not Significance \\
WLB $\longleftarrow$ PSD & -.119 & -.111 & .061 & -1.944 & .050 & Significance \\
\hline
\end{tabular}

In the above model, perceived work role demands had a negative effect on work - life balance $(\beta=-0.503, \mathrm{p}=$ $0.000)$, perceived family role demands had a negative and no significant effect on work - life balance $(\beta=-0.068$, $\mathrm{p}=-0.353)$ and perceived social role demands had a negative and significant effect on work - life balance $(\beta=$ $-0.111, \mathrm{p}=0.050)$. Accordingly, the following hypotheses were tested and presented in the following Table 11 . 
Table 11. The results of hypothesis testing for the respective paths

\begin{tabular}{|c|c|c|c|}
\hline Hypothesis Statement of Path Analysis & $\begin{array}{l}\text { Standard } \\
\text { Estimates }(\beta)\end{array}$ & p-value & $\begin{array}{l}\text { Results } \\
\text { hypothesis }\end{array}$ \\
\hline $\begin{array}{l}\text { H1a: Perceived work role demands have a significant \& negative impact on } \\
\text { work - life balance. }\end{array}$ & -.503 & .000 & Supported \\
\hline $\begin{array}{l}\text { H1b: Perceived family role demands have a significant \& negative impact on } \\
\text { work - life balance. }\end{array}$ & -.068 & -.353 & Not Supported \\
\hline $\begin{array}{l}\text { H1c: Perceived social role demands have a significant \& negative impact on } \\
\text { work - life balance. }\end{array}$ & -.111 & .050 & Supported \\
\hline
\end{tabular}

4.7 Results of Combined Impacts of Perceived Role Demands on Work - Life Balance and Hypothesis Testing

To test the degree of combined impacts of perceived role demands on work - life balance, stepwise multiple regression analysis using SPSS 23 has been carried out and the results are presented in Table 12.

Table 12. Combined impacts of perceived role demands towards work - life balance

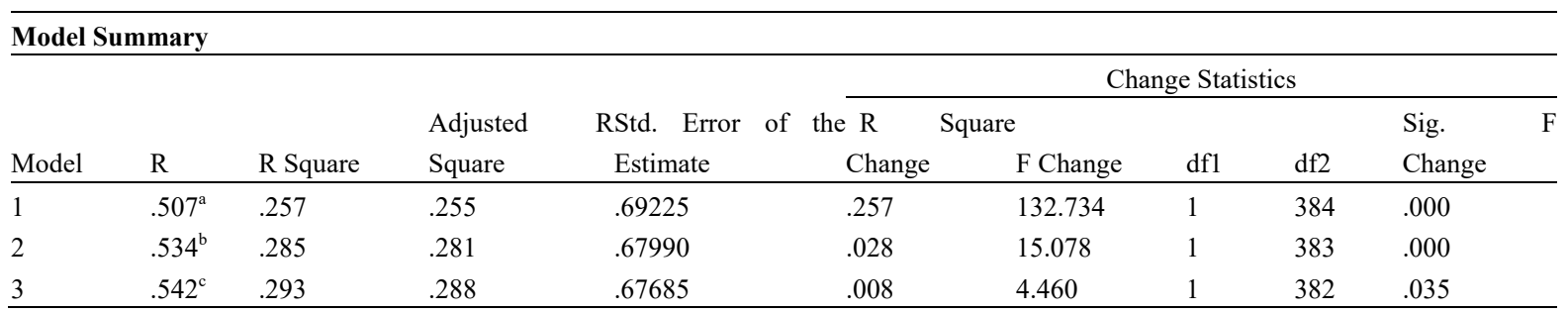

a. Predictors: (Constant), PWD; b. Predictors: (Constant), PWD, PFD; c. Predictors: (Constant), PWD, PFD, PSD.

According to the results of the above Table 12, overall correlation coefficient $(\mathrm{R})$ of the three predictor variables and WLB was .542 and the R Square was .293 with significant at .035 . It implies that about 29.3 percent of the variance of WLB has been significantly explained by the three predictor variables with greater predictive power. Furthermore, multiple correlation coefficient $(\mathrm{R})$ of the two independent variables of work role demands and family role demands (Model 2) and WLB was .534 and the R Square was .285 with significance at .000 . Therefore, there is statistical evidence to claim to the hypothesis (H1d) that the degree of combined impacts of work role demands, family role demands and social role demands have jointly and significantly impact on work life balance.

\subsection{Results of Correlations among Study Variables and Hypothesis Testing}

In the next step, Pearson coefficient of correlations were calculated to find out the relationship between perceived role demands and work - life balance relationships. With respect to this correlation matrix as shown in Table 13, perceived work role demand was found to be negatively and significantly correlated with work - life balance $(\mathrm{r}=-.507, \mathrm{p}=.000)$ and this relationship is strongest. Perceived family demands was found to be negatively and significantly correlated with work - life balance $(r=-.434, p=.000)$ and perceived social demands was found to be negatively and significantly correlated with work - life balance $(\mathrm{r}=-.246, \mathrm{p}=.000)$. This estimation supports the second hypothesis (H2) of perceived work role demand has the strongest relationship with work-life balance than that of perceived family or social role demands and work-life balance relationships.

Table 13. Correlation Matrix between work - life balance and role demands

\begin{tabular}{llll}
\hline Variables & WLB & PWD & PFD \\
\hline 1.WLB & 1 & & \\
2.PWD & $-.507^{* *}$ & 1 & \\
3.PFD & $-.434^{* *}$ & $.588^{* *}$ & 1 \\
4.PSD & $-.246^{* *}$ & $.210^{* *}$ & $.392^{* *}$ \\
\hline
\end{tabular}

\footnotetext{
**. Correlation is significant at the 0.01 level (2-tailed).
} 


\subsection{Results of the Moderating Effects of Work Ethics and Hypotheses Testing}

To test the moderating effect of work- ethics using multi group analysis in Amos (Bae, B., 2011, Zainudeen, 2014), the original data was split into two groups' namely High Work -Ethics Group (200) and Low- Work Ethics Group (186) data sets based on mean Work- Ethics value. In the basic model, using the data set of low work- ethics group a parameter constraint to be equal to 1 is put where the moderation test is to be carried out and this model is called as constrained model. Unconstraint model using the same data set was developed. The difference in Chi - square value between the constrained and the unconstrained model was calculated. If a change of the degree of freedom is 1 and the result is statistically significant at 0.05 level and the variation of $\chi^{2}$ is larger than 3.84, then it was concluded that the moderation occurs in that path. Same procedure was repeated for high work- ethics group. Accordingly, Table 14 presents the results of the moderating effects for both groups.

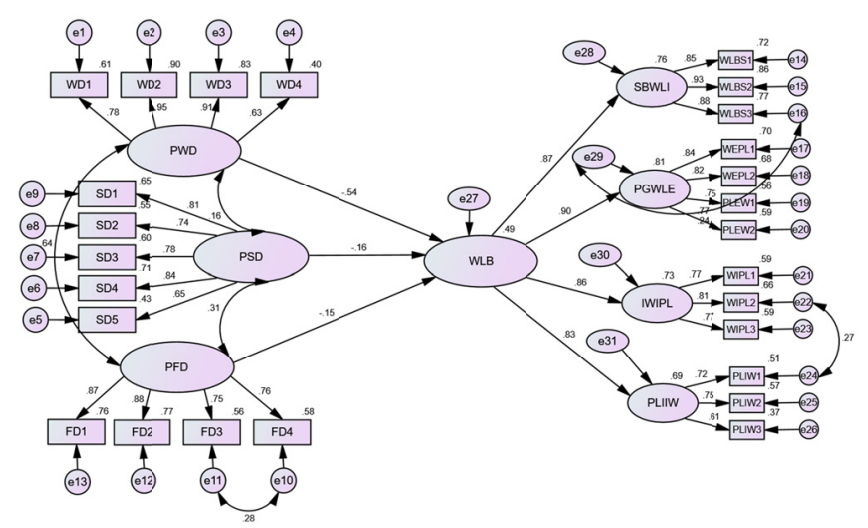

Figure 4. Unconstrained modified structural model with low Work- Ethic Group

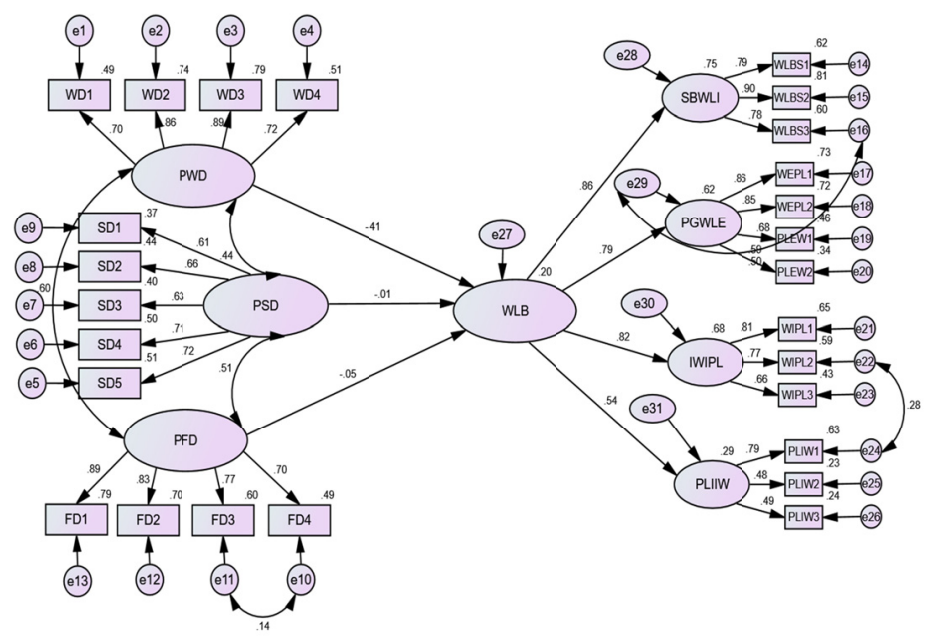

Figure 5. Unconstrained modified structural model with high Work -Ethic Group

Table 14. Results of moderating effects of Work - Ethics using multi group CFA analysis in Amos 21

\begin{tabular}{|c|c|c|c|c|c|c|}
\hline Independent & Dependent & Ethics Group & Constrained Model $\chi^{2}$ (d.f. & Unconstrained & Model & $\Delta \chi 2($ d.f. $=1)$ \\
\hline PWD & \multirow{6}{*}{$\begin{array}{ll}\text { Work } & -\mathrm{L} \\
\text { balance } & \end{array}$} & High & 650.436 & 569.424 & & 81.012 \\
\hline PFD & & High & 616.652 & 569.424 & & 47.228 \\
\hline PSD & & High & 615.880 & 569.424 & & 46.456 \\
\hline PWD & & Low & 665.341 & 501.144 & & 164.197 \\
\hline PFD & & Low & 588.566 & 501.144 & & 87.422 \\
\hline PSD & & Low & 586.127 & 501.144 & & 84.983 \\
\hline
\end{tabular}


As seen from Table 14 illustrations, the results revealed that moderation is significant for high work-ethics group and low work-ethics group between perceived work, family and social role demands and work -life balance relationship since the differences in Chi- square value between constrained and unconstrained model is more than 3.84 for all three cases for one degree of freedom at 0.000 significance levels. This results support the hypothesis (H3a) of Work Ethics has a moderating effect on the relationship between perceived work, family and social role demands and work-life balance relationships. Since both low work- ethics group and high workethics group moderation estimates are significant, partial moderation occurs in that path (Bae, 2011). As can be seen from the Figure 4, the output of the unconstrained modified structural model with low work ethic group, it was found the direct effect of $\beta=-0.54, p=0.000$ and as can be seen from the Figure 5, the output of the unconstrained modified structural model with high work ethic group, it was also found the direct effect of $\beta$ $=-0.41, p=0.000$. Furthermore, the paths between perceived family and social role demands and WLB were constrained and analyzed using both groups separately. It was found with low work- ethic group, the $\beta=-0.885$, $p$ $=0.000$ and high work ethic group, the $\beta=-0.857, p=0.000$. These findings shows that low work- ethics group has a higher effects than high work- ethics group on the moderation effects between perceived work role demands and work-life balance relationship. This results supports the Hypothesis (H3b) of the effects of perceived work role demands on work-life balance will be different between the group with high level of Work-Ethics and the group with low level of Work-Ethics.

\section{Discussions}

The results of this study show that professionals possess a moderate level of work - life balance (mean value was 3.01 with a standard deviation of 0.80 ). It was also identified that majority of the respondents (37.05\%) perceives high level of work-life balance while $32.12 \%$ of the respondents perceive low level of work-life balance whereas $30.83 \%$ of the respondents perceive moderate level of work-life balance in accordance with 1 to 5 Likert scale.

The output of the modified structural model indicates that Goodness of Fit Index (GFI) was 0.879 and Normed Fit Index (NFI) was 0.887 showing an overall good fit of the model. Similarly, the Root Mean Square Error of Approximation (RMSEA) yields a good fit of 0.061 and Root Mean Square Residual (RMR) is 0.086 . Moreover, Comparative Fit Index (CFI) was 0.930, Tucker- Lewis Index (TLI) was 0.921 and Normed Fit Index (NFI) was 0.887.These indices are within the standard values. Furthermore, the model yields CMIN/DF value of 2.425 which is within the threshold value of less than 3.0. These overall indices show that the model fits the data very well. In the above SEM model, perceived work role demands had a strongest negative impacts on work -life balance $(\beta=-0.503, p=0.000)$ while perceived social role demands had a moderate negative impacts on work life balance $(\beta=-0.111, p=0.05)$ but the weakest, negative and no significant effect was observed in perceived family role demand and work - life balance $(\beta=-0.068, p=-0.35)$ path. This findings of negligible effects of perceived family role demand is still noteworthy because it may reflect the reality of professionals. The findings of the study shows that the hypothesis which states that perceived role demands have a negative impact on work -life balance is evidence only for perceived work and social demands but no significance for family role demand.

Furthermore, multivariate Pearson correlation analysis provides the evidence that the strongest, negative and significant correlations was found between perceived work role demand and work -life balance $(\mathrm{r}=-.507, \mathrm{p}=.000)$, perceived family role demand was found to be negatively and significantly correlated with work -life balance $(\mathrm{r}=$ $-.434, \mathrm{p}=.000$ ) and perceived social role demand was found to be negatively and significantly correlated with work -life balance $(r=-.246, p=.000)$. This specifies that if perceived role demands are increased, the work-life balance is decreased and vice versa. This finding is consistent with the results of Lewis \& Cooper (1987) who reports that role demand is well documented source of pressures experienced by employees when balancing work and family. Moreover, from the output of stepwise multiple regression analysis using SPSS 23, R Square was .293 with significant at .035 . It implies that about 29.3 percent of the variance of work-life balance has been significantly explained by perceived work, family and social demands variables with greater predictive power which shows evidence for the combined effects of perceived role demands on work-life balance.

Work- Ethics has a moderating effect on the relationship between work, family and social role demands and work -life balance relationship were supported. According to Multi- Group CFA, the estimates for both the constrained and unconstrained model, Chi-Square value differs by more than 3.84 so that the moderation occurs in that paths in such a way that work- ethics has a moderating effect between perceived role demands and work life balance relationships. Since both low work- ethics group and high work- ethics group moderation estimates are significant, partial moderation occurs in that path. Finally, the present study also suggest from SEM analysis that effect size for low work- ethics group, the $\beta=-0.885, p=0.000$ and high work- ethic group, the $\beta=-0.857, p$ $=0.000$ and this shows that low work- ethic group has a higher effect than high work- ethics group for 
moderating the effect between perceived work role demands and work-life balance relationships. Moreover, this findings also suggest the notion that in a higher work - ethics group ethical behavior is inherent and existing in their value system and so role demands causes less effects.

\section{Conclusions}

In this study, a model has been tested which posits that perceived role demands affect work-life balance. This investigation demonstrated that professionals involved in this study possess a moderate level of work - life balance and having moderate level for all its dimensions. The overall results of the SEM model fit indices indicates that the data fit the model very well. Furthermore, this study verified that perceived work and social role demands have negative and significant causal impacts on work-life balance while no significant causal effect was found by family demands. This findings elucidated that work-life balance is skewed towards works and less in family and social role demand is also an emerging issue for professionals. Besides, statistical evidence was also found to claim that the degree of combined impacts of perceived role demands have jointly and significantly impact on work - life balance. Moreover, this study provides some further important insights that negative and significant correlations were found between perceived role demands and work-life balance and the strength of the relationship is higher for work demands then family demands and least for social demands. More precisely, this study added to generate the empirical evidence for work ethics has a partial moderation effect between perceived role demands and work - life balance relationships. Furthermore, it is one of the few studies through which moderation analysis investigates how low work- ethics group has higher effects than high work- ethics group on moderating the relationship between perceived work role demands and work-life balance relationship of public sector professionals in Sri Lanka. It serve as a reference landmark for public sector organizations to cultivate high work ethics culture among their employees.

\section{Implications, Recommendations, Limitations and Direction for Future Research}

\subsection{Implications and Recommendations}

This study is significant and beneficial for managers, organizational leaders and researchers to address the needs of employees and to initiate creative thinking to develop strategies and policies to combat or address the work life balance issues in an effective and efficient way. Moreover, this study is proved to be a milestone and crucial to professionals, employees and family members for better understanding how different role demands influence work - life balance. Furthermore, this study helped the professionals to understand the importance and a background for their current status of work - life balance in a context in which professional live.

\subsection{Limitations and Direction for future Research}

The first and foremost limitations of the study are that all of the measures were self-reported that common method bias may raise concern. Another limitation is that the research design is cross sectional survey and it would constraints for the true causality. Hence, further studies using longitudinal design would be useful in establishing the temporal order of relationship and insights of strong causal relationships among variables. Since the focal point of this study is public sector, future study also could be conducted among the private sector professionals in Sri Lanka.

\section{References}

Anitha, R., \& Muralidharan, D. (2014). A Study on the influence of Demographic and work related aspects on the work life balance of marketing Professional. Global Journal for Research Analysis, 3(11), 100-102.

Aziz, A., \& Chang, A. (2013). Work-family balance: The 3-way interaction effect of role demands, collectivism value and ethnicity. Journal of Global Management, 6, 22-39.

Bae, B. (2011). Structural Equation Modeling with AMOS 19: Principles and Practice. Cheongram Book: Seoul, Korea.

Boyar, S. L., Carr, J. C., Mosley, D. C. Jr., \& Carson, C. M. (2007). The development and validation of scores on perceived work and family demand scales. Educational and Psychological Measurement, 67, 100-115. https://doi.org//10.1177/0013164406288173

Boyar, S. L., Maertz, C. P., Mosley, D. C. Jr., \& Cars, J. C. (2008). The impacts of work / family demand on work-family conflict. Journal of Managerial Psychology, 23(3), 215-235. https://doi.org/10.1108/02683940810861356

Breitenecker, R. J., \& Shah, S. A. M. (2018). Relation of work-life balance, work-family conflict, and familywork conflict with the employee performance-moderating role of job satisfaction. South Asian Journal of Business Studies, 7(1), 129-146. 
Carlson, D. S., \& Kacmar,K.M.(2000). Work-Family Conflict in the organization :Do Life Role Values make a difference. Journal of management, 26(5), 1031-1054. https://doi.org/10.1177/014920630002600502

Carlson, D. S., Grzywacz, J. G., \& Zivnuska, S. (2009). Is work-family balance more than conflict and enrichment? Human Relations, 62(10), 1459-1486. https://doi.org/10.1177/0018726709336500

Casper, W., Vaziri, H., Wayne, J. H., DeHauw, S., \& Greenhaus, J. (2018). The Jingle-Jangle of Work-Nonwork Balance: A Comprehensive and Meta-Analytic Review of Its Meaning and Measurement. Journal of Applied Psychology, 103(2), 182-214. http:// doi.org /10.1037/ap10000259

Clark, S. C. (2000). Work/family border theory: A new theory of work/family balance. Human relations, 53(6), 747-770. https://doi.org/10.1177/0018726700536001

Crooker, K., Faye, L. S., \& Filliz, T. (2002). Creating Work-Life Balance: A model of pluralism across life domains, Human Resources Development Review, 1(4), 387-419. https://doi.org/10.1177/1534484302238434

Department of Census and Statistics. (2020). Sri Lanka Labour Force Survey, Sri Lanka.

Devadoss, A. V. J. M. (2013). A Study of Personality Influence in Building Work Life Balance Using Fuzzy Relation Mapping (FRM).The International Journal of Data Mining Techniques and Applications, 2, 211-216

Duxbury, 1., Higgins, C., \& Lee, C. (1993). The Impact of Job Type and Family Type on Work-Family Conflict and Perceived Stress: a comparative analysis. Resources humaines, 14, 21-29.

Eaton, S. C. (2003). If you can use them: Flexibility policies, organizational commitment and perceived performance. Industrial Relations, 42(2), 145-167. https://doi.org//10.1111/1468-232X.00285

Field, A. (2009). Discovering Statistics using SPSS $3^{\text {rd }}$ Edition. SAGE Publications Inc., p.648.

Fisher-McAuley, G., Stanton, J., Jolton, J., \& Gavin, J. (2003). Modelling the relationship between work life balance and organizational outcomes. Paper presented at the Annual Conference of the Society for Industrial-Organizational Psychology.

Fornell, C., \& Larcker, D. F. (1981). Evaluating structural equation models with unobservable variables and measurement error. Journal of Marketing Research, 18(1), 39-50. https://doi.org//10.2307/3151312.

Frone, M. R. (2003). Work-family balance. In J. C. Quick \& L. E. Tetrick (Eds.), Handbook of Occupational Health Psychology. Washington D. C.: American Psychological Association. https://doi.org//10.1037/10474-007

Greenhaus, J. H., \& Powell, G. N. (2003). When Work and Family Collide: Deciding between Competing Role Demands. Organizational Behaviour and Human Decision Processes, 90, 291-303. https://doi.org//10.1016/S0749-5978 (02)00519-8

Greenhaus, J. H., Collins, K. M., \& Shaw, J. D. (2003). The relation between work family balance and quality of life. Journal of vocational behavior, 63, 500-531. https://doi.org//10.1016/S0001-8791(02)00042-8

Greenhaus, G. H., \& Allen, T. D. (2010). Work-family balance: a review and extension of the literature, in Tetrick, L. and Quick, J. C. (Eds), Handbook of Occupational Health Psychology (2nd ed.). American Psychological Association, Washington, DC.

Grzywacz, J. G., \& Carlson, D. S. (2007). Conceptualizing work- family balance: Implications for practice and research. Advances in Developing Human Resources, 9, 455-471. https://doi.org/10.1177/1523422307305487

Hayman, J. (2005). Psychometric assessment of an instrument designed to measure work life balance. Research and Practice in Human Resource Management, 13, 85- 91.

Higgins, C., Duxbury, L., \& Johnson, K. L. (2000). Part-time work for women: does it really help balance work and family? Human Resource Management, $17-32$. https://doi.org/10.1002/(SICI)1099-050X(200021)39:13.3.CO; 2-P

Jyothi, V. S. (2011). Work-Life Balance among Women Employees in Organizations: A Study in Andhra Pradesh. Shodhganga, 1-29.

Kalliath, T., \& Brough, P. (2008). Work-life balance: A review of the meaning of the balance construct. Journal of Management \& Organization, 14, 323-327. https://doi.org/10.5172/jmo.837.14.3.323 
Katz, D., \& Kahn, R. (1978). The social psychology of organizations. New York: Wiley.

Kelliher, C. (2016). Work-life balance. In A. Wilkinson, \& S. Johnstone (Eds.), Encyclopedia of human resource management. Cheltenham, UK: Edward Elgar.

Kelliher, C., Richardson, J., \& Boiarintseva, G. (2018). All of work? All of life? Reconceptualising work-life Balance for the 21st century. Human Resources Management Journal, 29(2), 97-112.

Kirchmeyer, C. (2000). Work-life initiatives: Greed or benevolence regarding workers' time? In C. L. Cooper \& D. M. Rousseau (Eds.), Trends in organizational behavior: Time in organizational behavior. Chichester, UK: Wiley.

Lambert, S. J. (1990). Processes linking work and family: a critical review and research agenda. Human Relations, 43(3), 239-257. https://doi.org/10.1177/001872679004300303

Lewis, S. N. C., \& Cooper, C. L. (1987). Stress in two-earner couples and stage in two life-cycle. Journal of occupational psychology, 60, 289-303. https://doi.org/10.1111/j.2044-8325.1987.tb00261.x

Marks, S. R., \& MacDermid, S. M. (1996). Multiple roles and the self: A theory of role balance. Journal of Marriage and the Family, 58, 417-432. http:// doi.org/10.2307/353506

Miller, M. J., Woehr, D. J., \& Hudspeth, N. (2001). The meaning and measurement of work ethic: Construction and initial validation of a multidimensional inventory. Journal of Vocational Behavior, 60, 451-489. https://doi.org/10.1006/jvbe.2001.1838

Nunnally, J.C. (1978). Psychometric theory (2nd ed.). New York: McGraw-Hill.

Oludayo, F., Obianuju, A., \& Demilade, F. (2018). Work-Life Balance Initiative as a Predictor of Employees Behavioural Outcomes. Academy of Strategic Management Journal, 17, 1-17.

Opatha, H. H. D. N. P., \& Teong, L. K. (2014). Enhancing Personal Q. Sintok: Penerbit University Utara, Malasia.

Pareek, U., \& Surabhi, P. (2010). Training Instruments in HRD and OD (3rd ed.). Tata McGraw Hill, India.

Paullay, I. M., Alliger, G. M., \& Stone-Romero, E. F. (1994). Construct validation of two instruments designed to measure job involvement and work centrality. Journal of Applied Psychology, 79(2), 224-228. https://psycnet.apa.org/doi/10.1037/0021-9010.79.2.224

Pleck, J. H. (1977).The work-family role system. Social Problems, 24(4), 417-427. https://doi.org/10.2307/800135

Rau, B. L., \& Hyland, M. M. (2002). Role conflict and flexible work arrangements: The effects on applicant attraction. Personnel Psychology, 55, 111-136. https://doi.org/10.1111/j.1744-6570.2002.tb00105.x

Reiter, N. (2007). Work life balance: What do you mean? The ethical ideology underpinning appropriate application. The Journal of Applied Behavioral Science, 43, 273-294. http://dx.doi.org/10.1177/0021886306295639

Sekaran, U., \& Bougie, R. (2013). Research Methods for Business (6th ed). United Kingdom: John Wiley \& Sons.

Semlali, S., \& Hassi, A. (2016). Work-life balance: how can we help women IT professionals in Morocco? Journal of Global Responsibility, 7(2), 210-225.

Sheikh, M., A., Ashiq, A., Mehar, M. R., Hasan, A., \& Khalid, M. (2018). Impact of Work and Home Demands on Work Life Balance: Mediating Role of Work Family Conflicts. Pyrex Journal of Business and Finance Management Research, 4(5), 48-57.

Shobitha, P., \& Sudarsan, N. (2014). Work Life Balance: A Conceptual Review, International Journal of Advances in Management and Economics, 3(2), 01-17.

Sirgy, M. J., \& Lee, D. J. (2017). Work-Life Balance: An Integrative Review. Applied Research in Quality of Life, $13,229-254$.

Sonia Delrose Noronha, P.S., Aithal \& Pradeep, M. D. (2017). Study on Policy Framework towards Work- Life Balance in India. International Journal of Multidisciplinary Research and Modern Education, 3(2), 11-16.

Sullivan, O. (2019). Gender inequality in work-family balance. Nature Human Behaviour, 3, 201-203.

Voydanoff, P. (1988).Work role charecteristics, family structure demands and work/family conflict. Journal of Marriage and the family, 50, 749-761. https://doi.org/10.2307/352644 
Voydanoff, P. (2004). The effects of work demands and resources on work-to-family conflict and facilitation. Journal of Marriage and Family, 66, 398-412. https://doi.org/10.1111/j.1741-3737.2004.00028.x

Voydanoff, P. (2004b). The effects of work and community resources and demands on family integration. Journal of Family and Economic Issues, 25, 7-23. https://doi.org /10.1023/ B: 3 JEEI. 0000016721. 71785.06

Wayne, J. H., Butts, M. B., Casper, W. J., \& Allen, T. D. (2017). In search of balance: A conceptual and empirical integration of multiple meanings of work-family balance. Personnel Psychology, 70, 167-210. https://doi.org/10.1111/peps.12132

Weber, M. (1958). The Protestant Ethic and the spirit of capitalism (T. Parsons, Trans.). New York: Scribner's.

Wilkinson, K., Tomlinson, J., \& Gardiner, J. (2017). Exploring the work-life challenges and dilemmas faced by managers and professionals who live alone, Work, Employment and Society, 31(4), 640-656.

Zainudeen, W. (2014). Analyzing the effect of a moderator in model: The Multi-Group CFA procedure in SEM. University of Sultan, Malaysia.

\section{Copyrights}

Copyright for this article is retained by the author(s), with first publication rights granted to the journal.

This is an open-access article distributed under the terms and conditions of the Creative Commons Attribution license (http://creativecommons.org/licenses/by/4.0/). 